\title{
Induction of Sustained Expression of Proto-oncogene c-fms by Platelet-derived Growth Factor, Epidermal Growth Factor, and Basic Fibroblast Growth Factor, and Its Suppression by Interferon- $\gamma$ and Macrophage Colony-stimulating Factor in Human Aortic Medial Smooth Muscle Cells
}

\author{
Toshimori Inaba, Takanari Gotoda, Kenji Harada, Masako Shimada, Jun-ichi Ohsuga, Shun Ishibashi, Yoshio Yazaki, and \\ Nobuhiro Yamada \\ The 3rd Department of Internal Medicine, Faculty of Medicine, University of Tokyo, Hongo, Tokyo, 113, Japan
}

\begin{abstract}
Vascular medial smooth muscle cells migrate, proliferate and transform to foam cells in the process of atherosclerosis. We have reported that the intimal smooth muscle cells express proto-oncogene $c$-fms, a characteristic gene of monocyte-macrophages, which is not normally expressed in medial smooth muscle cells. In the present study, we demonstrated that combinations of platelet-derived growth factor (PDGF)-BB and either epidermal growth factor (EGF) or fibroblast growth factor (FGF) induced high expression of $c$-fms in normal human medial smooth muscle cells to the level of intimal smooth muscle cells or monocyte-derived macrophages, whereas $c$-fms expression by PDGF-BB alone was $1 / 10$ and both EGF and FGF had no independent effect on $c$-fms expression. By contrast, interferon (IFN)- $\gamma$ and macrophage colony-stimulating factor (M-CSF) suppressed the induction of $c$-fms expression. These results indicate that multiple growth factors and cytokines may play a role in the phenotypic transformation of medial smooth muscle cells to intimal smooth muscle cells in atherosclerotic lesions by altering $c$-fms expression. (J. Clin. Invest. 1995. 95:11331139.) Key words: $c$-fms • PDGF • EGF • M-CSF • smooth muscle cell $\bullet$ atherosclerosis
\end{abstract}

\section{Introduction}

In atherosclerotic lesions, vascular smooth muscle cells undergo structural and functional changes from a contractile to a synthetic phenotype, in particular, transform into foam cells in the intima by actively taking up lipoprotein cholesterol through receptor-mediated endocytosis $(1-3)$. We have previously demonstrated that vascular smooth muscle cells isolated from the intima of atherosclerotic lesions express, a characteristic gene of monocyte-macrophages, $c$-fms (4), suggesting not only that the mechanism underlying the process of atherosclerosis induces alterations in the regulation of normal $c$-fms gene expression in vascular smooth muscle cells but also that factors

Address correspondence to Nobuhiro Yamada, The 3rd Dept. of Internal Medicine, Faculty of Medicine, University of Tokyo, Hongo, Tokyo, 113, Japan. Phone: 81-3-3815-5411; FAX: 81-3-5802-2955. 1994.

Received for publication 7 July 1994 and in revised form 8 October

J. Clin. Invest.

(c) The American Society for Clinical Investigation, Inc.

0021-9738/95/03/1133/07 \$2.00

Volume 95, March 1995, 1133-1139 inducing $c$-fms gene expression in vascular smooth muscle cells play an important role in the process of atherosclerosis. Cells expressing $c$-fms can respond to macrophage colony-stimulating factor (M-CSF), ${ }^{1}$ an 85-kD homodimeric glycoprotein, through binding to specific high-affinity surface receptors encoded by $c$-fms that constitute one member of a family of growth factor receptors with intrinsic tyrosine kinase activity. The rapid phosphorylation at tyrosine initiates a cascade of metabolic and gene regulatory events (5-8). The expression of the $c$-fms gene in vascular smooth muscle cells initiates biological events including cell surface binding of M-CSF, tyrosine-phosphorylation of $M-C S F$ receptor, and an increased rate of cell proliferation in response to $\mathrm{M}-\mathrm{CSF}$, and vascular smooth muscle cells expressing $c$-fms transform into foam cells by taking up modified low density lipoprotein (LDL) (4).

In atherosclerotic process, various cytokines and growth factors play important roles in phenotypic changes of vascular smooth muscle cells (3). We have recently demonstrated that platelet-derived growth factor (PDGF)-BB induces $c$-fms expression in medial smooth muscle cells, however, the induced mRNA level of $c$-fms is transient and extremely low as compared to its expression in monocyte-derived macrophages or intimal smooth muscle cells isolated from the intima of atherosclerotic lesions (9). Our observations suggest that other growth factors and cytokines in addition to PDGF-BB are required for stable and high expression of $c$-fms in vivo. In the present study, we investigated factors that are involved in the regulation of $c$ fms expression in normal vascular smooth muscle cells, to define the mechanism underlying the process of atherosclerosis.

\section{Methods}

Materials. Recombinant human PDGF-BB homodimer, recombinant human epidermal growth factor (EGF), and recombinant human basicfibroblast growth factor (FGF) were purchased from Genzyme Co. (Boston, MA). Recombinant human interferon (IFN)- $\gamma$, and recombinant human endothelin-1 were obtained from Shionogi Pharmaceutical Co. (Osaka, Japan) and Peptide Institute Inc. (Osaka, Japan), respectively. Recombinant human M-CSF was a purified product obtained from Morinaga Milk Industry Co., Ltd. (Tokyo, Japan) $(4,9)$. Dibutyryl cyclic AMP, insulin, PMA, pertussis toxin, cycloheximide, and staurosporine were obtained from Sigma Chemical Co. (St. Louis, MO). DME was obtained from GIBCO BRL (Gaithersburg, MD). All other chemicals were of analytical grade.

Cells. Human aortic medial smooth muscle cells were explanted from the human aorta by the method of Fischer-Dzoga et al. $(9,10)$.

1. Abbreviations used in this paper: CAT, chloramphenicol acetyltransferase; FGF, fibroblast growth factor; M-CSF, macrophage-stimulating factor. 
The cells were passaged three times by trypsinization and seeded in 10 $\mathrm{ml}$ of DME containing $10 \%$ FCS in 100-mm dishes. Subconfluent cells were cultured with $10 \mathrm{ng} / \mathrm{ml}$ PDGF-BB and various growth factors in DME containing $1 \% \mathrm{FCS}$ for $8 \mathrm{~h}$ at $37^{\circ} \mathrm{C}$ after a $24-\mathrm{h}$ preincubation in serum-free medium. Rabbit medial and intimal smooth muscle cells were cultured and subconfluent cells were used for experiments as described previously $(4,9)$. Monocytes were isolated from peripheral blood of a normolipidemic healthy donor using the Ficoll-Hypaque gradient method as described previously $(11,12)$. The cells were used as monocyte-derived macrophages after $9 \mathrm{~d}$ of culture (13).

Quantitative analysis of $M-C S F$ receptor $m R N A$ and Northern blot analysis. Total RNA was isolated from cultured smooth muscle cells by the acid-guanidine phenol chloroform method (14). A competitive PCR method was used to measure M-CSF receptor ( $c$-fms) mRNA levels as previously described $(3,15,16) .1 \mu \mathrm{g}$ of total RNA was reverse-transcribed with random hexamer primers. The DNA fragment of human $c$-fms gene ( $240 \mathrm{bp}$ ) was preparatively amplified with a pair of primers and used in the competitive PCR as a control template. Aliquots of the cDNA products were coamplified with indicated amounts of the control genomic DNA (240 bp). The amplified fragments of cDNA ( $164 \mathrm{bp}$ ) lack an intron.

Blot hybridization studies were performed for $c$-fms mRNA of human smooth muscle cells. $10 \mu \mathrm{g}$ of total RNA was electrophoretically fractionated on $1 \%(\mathrm{wt} / \mathrm{vol}$ ) agarose $/ 2.2 \mathrm{M}$ formaldehyde gel and transferred onto a nylon membrane. The membrane was hybridized with the cDNA probe for human $c$-fms (9). The filters were washed in $2 \times$ SSC ( $1 \times$ SSC: $150 \mathrm{mM} \mathrm{NaCl}, 10 \mathrm{mM}$ sodium citrate) and $0.5 \%$ (wt/vol) SDS at room temperature for $15 \mathrm{~min}$ twice, then in $0.2 \times \mathrm{SSC}$ and $0.5 \%$ (wt/vol) SDS at $65^{\circ} \mathrm{C}$ for $15 \mathrm{~min}$, and finally exposed to radiographic films at $-80^{\circ} \mathrm{C}$

Ribonuclease protection assay. A 1.2-kb Pst I fragment (20483194) of the human $c$-fms cDNA was subcloned into pBluescript II SK (-) (Stratagene Corp., La Jolla, CA), and this plasmid was digested with $\mathrm{Bgl}$ II. The digested DNA was transcribed and labeled with [ $\alpha$ ${ }^{32} \mathrm{P}$ ] UTP ( specific activity, $800 \mathrm{Ci} / \mathrm{m} \mathrm{mol}$; Amersham Corp., Arlington, IL) using Riboprobe Gemini System according to the method described in the instruction (Promega Corp., Madison, WI). A resultant 354bp antisense RNA probe was used for ribonuclease protection assay. Ribonuclease protection assay was performed by the method described in the instruction of Ribonuclease protection assay kit (Ambion Inc., Austin, TX). $10 \mu \mathrm{g}$ of total RNA was hybridized with $\sim 20,000 \mathrm{cpm}$ of the RNA probe overnight at $42^{\circ} \mathrm{C}$, and then digested with the mixture of RNase A and RNase T1. A specific RNA for human $c$-fms that was protected from digestion, was separated on a $8 \mathrm{M}$ urea sequencing gel.

In vitro transcription assay. The bacterial chloramphenicol acetyltransferase (CAT) and the SV40 enhancer were isolated from pCATcontrol plasmid (Promega) as a 1.9-kbp HindIII-SalI fragment. A 550bp SacI fragment (-606 to -56) containing 5 ' non-coding region of $c$-fms genomic DNA (17) was introduced into the pBS-CAT/SV40 plasmid containing a 1.9-kbp HindIII-SalI fragment in pBluescript II $\mathrm{KS}(-)$ $(18)$, in a sense orientation immediately upstream of the CAT gene. CAT plasmid and control $\beta$-galactosidase plasmid (pSV- $\beta$-Gal) (Promega) were introduced into human aortic smooth muscle cells as follows; subconfluent cells, cultured on a 35-mm dish, were cotransfected with lipofectin. Both CAT plasmid $(1.5 \mathrm{mg})$ and $\mathrm{pSV}-\beta-\mathrm{Gal}(0.5 \mathrm{mg})$ were mixed with $10 \mathrm{ml}$ of Lipofectin Reagent (GIBCO BRL). After a 15-min incubation with foam lipid-DNA complex at room temperature, the mixture was added to the culture medium of Opti-MEM I Reduced Serum Medium (GIBCO BRL), which was exchanged just before transfection. After $8 \mathrm{~h}$, the culture medium was replaced by DMEM (GIBCO BRL) containing $10 \%$ FCS. After $56 \mathrm{~h}$, the medium was supplemented with PDGF-BB ( $10 \mathrm{ng} / \mathrm{ml})$ and/or EGF $(3 \mathrm{ng} / \mathrm{ml})$, and was incubated subsequently for $4 \mathrm{~h}$. The cells were harvested for measurement of CAT (19) and $\beta$-galactosidase activity as described by Herbomel et al. (20). In brief, transfected cells were washed three times with phosphatebuffered saline, scraped into $500 \mu \mathrm{l}$ of the lysis buffer of $40 \mathrm{mM}$ Tris$\mathrm{HCl}$ buffer, $\mathrm{pH} 7.4$, containing $1 \mathrm{mM}$ EDTA and $150 \mathrm{mM} \mathrm{NaCl}$, lysed by shearing through a 25 -gauge needle 10 times, and centrifuged at
$14,000 \mathrm{~g}$ for $2 \mathrm{~min}$ at $4^{\circ} \mathrm{C}$. An aliquot of the supernatant $(20 \mu \mathrm{g})$ was incubated for $1 \mathrm{~h}$ at $37^{\circ} \mathrm{C}$ in a standard CAT assay in a final volume of $0.15 \mathrm{ml}$ of containing $0.9 \mathrm{nmol}$ of $\left[{ }^{14} \mathrm{C}\right]$ chloramphenicol $(50 \mathrm{nCi})$ (Amersham) and $0.53 \mathrm{mM}$ butyryl-CoA. All assays were linear with respect to incubation time and concentration of extract protein. The reaction products were chromatographed on Merck 5748 silica gel plates developed in a chloroform/methanol ( $95: 5 \mathrm{vol} / \mathrm{vol})$ solvent system, and finally exposed to radiographic films at $-80^{\circ} \mathrm{C}$. Then, butyrated products were scraped and counted. Each cell lysate was simultaneously analyzed for CAT enzyme activity and control plasmid $\beta$-galactosidase activity. The measured CAT activity was normalized relative to $\beta$-galactosidase activity.

DNA synthesis and uptake of acetylated $L D L$. Subconfluent cells were used, and medium was replaced with serum-free RPMI 1640 for $48 \mathrm{~h}$ before the experiment. After incubating with human PDGF-BB and/or human EGF in RPMI 1640 containing $1 \%$ fetal calf serum for $24 \mathrm{~h}, 1 \mu \mathrm{Ci} / \mathrm{ml}$ of $\left[{ }^{3} \mathrm{H}\right]$ thymidine $(1 \mathrm{mCi} / \mathrm{ml}$; NEN Research Products, Boston, MA) was added. Incubation was performed for $4 \mathrm{~h}$, and then the radioactivity in the cells was determined (4).

LDL $(\mathrm{d}=1.019-1.063 \mathrm{~g} / \mathrm{ml})$ was prepared from human plasma containing $0.1 \%$ EDTA, $0.02 \%$ sodium azide, and $0.5 \mathrm{mg} / \mathrm{ml}$ benzamidine, from fasted normolipemic volunteers, and isolated by sequential ultracentrifugation in a 50.2 Ti rotor (Beckman Instruments, Palo Alto, CA ) as described previously $(21,22)$. LDL was acetylated by repetitive additions of acetic anhydride $(13,23)$ and lipoproteins were radioiodinated with $\mathrm{Na}^{125} \mathrm{I}$ using the iodine monochloride method $(24,25)$. Subconfluent cells were cultured with PDGF-BB and/or EGF in DME containing $1 \% \mathrm{FCS}$ for $8 \mathrm{~h}$ at $37^{\circ} \mathrm{C}$ after a $24-\mathrm{h}$ preincubation in serumfree medium, and further incubated with PDGF-BB and/or EGF in the presence of $10 \mu \mathrm{g} / \mathrm{ml}^{125} \mathrm{I}$-acetylated LDL for $5 \mathrm{~h}$ at $37^{\circ} \mathrm{C}$ to study cell association and degradation of ${ }^{125} \mathrm{I}$-acetylated LDL. Cell association and degradation of ${ }^{125} \mathrm{I}$-acetylated LDL were determined by the method described previously $(13,26)$. Nonspecific cell association and degradation were determined by the addition of a 50 -fold excess of unlabeled acetylated LDL.

\section{Results}

$c$-fms $m R N A$ analysis. The mRNA of $c$-fms was not detected in human aortic smooth muscle cells using northern blot hybridization with a cDNA probe of $c$-fms as we reported $(4,9)$. Even when $10 \mathrm{ng} / \mathrm{ml}$ PDGF-BB induced the gene expression of $c$-fms in human aortic smooth muscle cells, mRNA was not detected in northern blot hybridization (9). In the presence of both $3 \mathrm{ng} / \mathrm{ml}$ EGF and $10 \mathrm{ng} / \mathrm{ml}$ PDGF-BB, mRNA of $c$ fms was detected in human aortic smooth muscle cells as a comparable mRNA level to that in human monocyte-derived macrophages (Fig. $1 \mathrm{~A}$ ). However, $c$-fms expression was not induced by these growth factors in human skin fibroblasts (unpublished observation).

To estimate the mRNA level of $c$-fms, we used a sensitive competitive polymerase chain reaction method. In this assay, the amplified fragments of cDNA (164 bp) were shorter than those of genomic DNA (240 bp) due to lack of an intron (Fig. $1 B$ ). Since cDNA and genomic DNA fragments can be coamplified with the same set of primers and their sizes are different, coamplification of the two fragments should occur in a concentration-dependent manner. It is possible to quantitate the amount of cDNA present, by titrating an unknown amount of cDNA against a dilution series containing known amounts of the corresponding genomic DNA. For instance, the same amounts of genomic DNA and cDNA fragments were obtained when the concentration of genomic template $(240 \mathrm{bp})$ was $8 \times 10^{-2} \mathrm{pg} /$ $\mu \mathrm{l}$ in the assay for the estimation of $c$-fms mRNA level in 


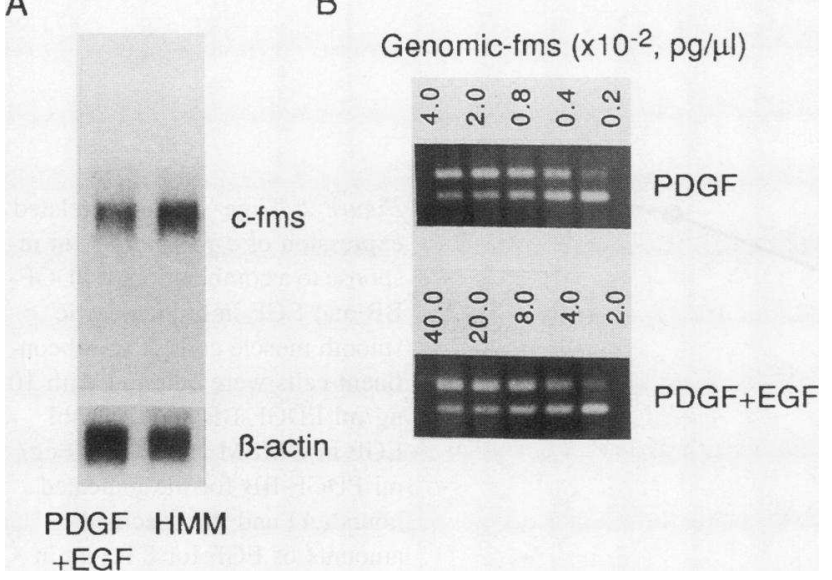

Figure 1. Northern blot hybridization analysis $(A)$ and quantitative analysis $(B)$ of M-CSF receptor mRNAs isolated from human aortic medial smooth muscle cells. Human aortic medial smooth muscle cells were explanted from the human aorta. Subconfluent cells were cultured with $10 \mathrm{ng} / \mathrm{ml}$ human PDGF-BB and $3 \mathrm{ng} / \mathrm{ml}$ human EGF in DMEM containing $1 \% \mathrm{FCS}$ for $8 \mathrm{~h}$ after a $24 \mathrm{~h}$ preincubation in serum-free medium Thereafter, $10 \mu \mathrm{g}$ of total RNA was applied to Northern blot hybridization with the cDNA probe for human $c$-fms. A competitive polymerase chain reaction method was used to measure M-CSF receptor ( $c$-fms) mRNA levels. $1 \mu \mathrm{g}$ of total RNAs isolated from the cells was reversetranscribed with random hexamer primers. Aliquots of the cDNA products were coamplified with indicated amounts of the control genomic DNA ( $240 \mathrm{bp}$ ). mRNA levels were estimated by titrating an unknown amount of cDNA (164 bp) against a dilution series containing known amounts of the corresponding genomic DNA.

human aortic smooth muscle cells in the presence of $10 \mathrm{ng} / \mathrm{ml}$ PDGF-BB and $3 \mathrm{ng} / \mathrm{ml}$ EGF (Fig. $1 B$ ).

In assays of human aortic smooth muscle cells in the presence of PDGF-BB only, the mRNA levels were estimated at 8 $\times 10^{-3} \mathrm{pg} / \mu \mathrm{l}$ genomic DNA (240 bp). These results indicate that the transcription of $c$-fms in human aortic smooth muscle cells was increased 10-fold in the presence of both PDGF-BB and EGF compared to PDGF-BB alone and that the induced mRNA level was comparable to those of human monocytederived macrophages and rabbit intimal smooth muscle cells ( 8 $\times 10^{-2}$ versus $17.5 \times 10^{-2}$ and $10 \times 10^{-2} \mathrm{pg} / \mu \mathrm{l}$, respectively, Table I). In agreement with these results, ribonuclease protection assay demonstrated that mRNA level of $c$-fms in human medial smooth muscle cells in the presence of both PDGF-BB and EGF was comparable to that in human monocyte-derived macrophages (data not shown).

We have previously reported that PDGF-AA, interleukin (IL) $-1 \beta$, IL-3, tumor necrosis factor- $\alpha$, insulin, endothelin-1, interferon- $\gamma$, noradrenalin, transforming growth factor- $\beta$, phorbol ester, and dibutyryl cyclic AMP do not induce $c$-fms expression (9). In the present study, we further found that $3 \mathrm{ng} / \mathrm{ml}$ EGF, $80 \mathrm{ng} / \mathrm{ml} \mathrm{IL-2,} 10 \mathrm{ng} / \mathrm{ml} \mathrm{IL-4,} 25 \mathrm{ng} / \mathrm{ml} \mathrm{IL-6,} \mathrm{and} 3 \mathrm{ng} /$ $\mathrm{ml}$ basic FGF did not induce $c$-fms expression in human aortic medial smooth muscle cells using a sensitive competitive PCR method.

We observed that $10 \mathrm{ng} / \mathrm{ml}$ PDGF-BB and $3 \mathrm{ng} / \mathrm{ml}$ EGF induced the expression of $c$-fms 8 to $12 \mathrm{~h}$ after their addition into the culture medium (Fig. $2 A$ ), and gene expression was enhanced $10^{3}$ to $10^{4}$-fold in response to both PDGF-BB and EGF in human aortic smooth muscle cells. This enhanced ex-
Table I. mRNA Expression of c-fms in Vascular Smooth Muscle Cells

\begin{tabular}{lcc}
\hline & $\begin{array}{c}\text { mRNA level } \\
\left(10^{-2} \mathrm{pg} / \mu \mathrm{l}\right)\end{array}$ & Fold \\
\hline Human monocyte-derived macrophage & 17.5 & 1.0 \\
Human aortic medial SMC & 0.002 & $1.1 \times 10^{-4}$ \\
Rabbit aortic medial SMC & 0.001 & $0.6 \times 10^{-4}$ \\
Rabbit aortic intimal SMC & 10.0 & 0.6 \\
& & \\
\hline
\end{tabular}

Rabbit intimal smooth muscle cells (SMC) were isolated from intima of balloon-injured aorta (4), and human monocyte-derived macrophages, human and rabbit aortic medial SMC were cultured as described in Methods. Total RNA was isolated from cells and levels of mRNA expression were estimated by a competitive polymerase chain reaction method and expressed as genomic $c$-fms concentrations $\left(10^{-2} \mathrm{pg} / \mu \mathrm{l}\right)$.

pression of $c$-fms was sustained at least $48 \mathrm{~h}$ after exposure to both PDGF-BB and EGF as compared to that by PDGF-BB alone. The effect of PDGF and EGF on $c$-fms expression was dose-dependent on concentrations of EGF (Fig. $2 \mathrm{~B}$ ). The amounts of RNA/cell were not significantly different among untreated cells, cells treated with PDGF alone, and cells treated with PDGF and EGF. In addition to EGF, $3 \mathrm{ng} / \mathrm{ml}$ basic-FGF and $100 \mathrm{nM}$ PMA enhanced the effect of PDGF-BB on $c$ fms expression (Table II), whereas insulin, endothelin-1, and dibutyryl cyclic AMP had no additional effect on $c$-fms expression induced by PDGF-BB (Tables II and III). Pretreatment of aortic smooth muscle cells with PMA for $24 \mathrm{~h}$ or staurosporine suppressed $c$-fms expression in the presence of both PDGF-BB and EGF to half of that in controls (Table III). As shown in Table III, pertussis toxin did not influence it, suggesting that pertussis toxin-sensitive $G$ protein was not involved in the enhanced expression of $c$-fms.

In contrast, $c$-fms mRNA levels in human aortic smooth muscle cells were only $8 \times 10^{-4} \mathrm{pg} / \mu \mathrm{l}$ in the presence of a combination with $10 \mathrm{ng} / \mathrm{ml}$ PDGF-BB and 50 units/ml IFN- $\gamma$ and $1.6 \times 10^{-3} \mathrm{pg} / \mu \mathrm{l}$ in the presence of a combination with $10 \mathrm{ng} / \mathrm{ml}$ PDGF-BB and $50 \mathrm{ng} / \mathrm{ml} \mathrm{M-CSF}$ (Table II). These results indicated the mRNA levels of $c$-fms in the presence of IFN- $\gamma$ and M-CSF were $1 / 10$ and $1 / 5$ that of PDGF-BB alone, respectively $\left(8 \times 10^{-4}\right.$ and $1.6 \times 10^{-3}$ versus $8 \times 10^{-3} \mathrm{pg} / \mu \mathrm{l}$, respectively). The addition of EGF reduced the inhibitory effect of M-CSF on mRNA expression of $c$-fms as compared to in the absence of EGF (Table III).

To study the effect of protein synthesis inhibition on $c$ fms expression by IFN- $\gamma$, subconfluent vascular smooth muscle cells were preincubated with $50 \mu \mathrm{g} / \mathrm{ml}$ cycloheximide for 15 min before the experiment and further incubated with $50 \mu \mathrm{g} /$ $\mathrm{ml}$ cycloheximide in the presence of both $10 \mathrm{ng} / \mathrm{ml}$ PDGF-BB and 50 units/ml IFN- $\gamma$ in DMEM containing 1\% FCS for $8 \mathrm{~h}$ after a 24-h preincubation in serum-free medium. $50 \mu \mathrm{g} / \mathrm{ml}$ cycloheximide did not influence the inhibitory effect of IFN- $\gamma$ on $c$-fms expression.

In vitro transcription study. A $0.55-\mathrm{kb}$ SacI fragment (-606 to -56) containing 5' non-coding region of c-fms genomic DNA was introduced immediately upstream from the CAT gene (Fig. $3 A$ ). Since the $0.55-\mathrm{kb}$ SacI fragment was reported to have no enhancer activity (17), an exogenous viral enhancer, the SV40 core enhancer, was introduced into CAT plasmid. The promoter constructs were transiently transfected into human aortic smooth 


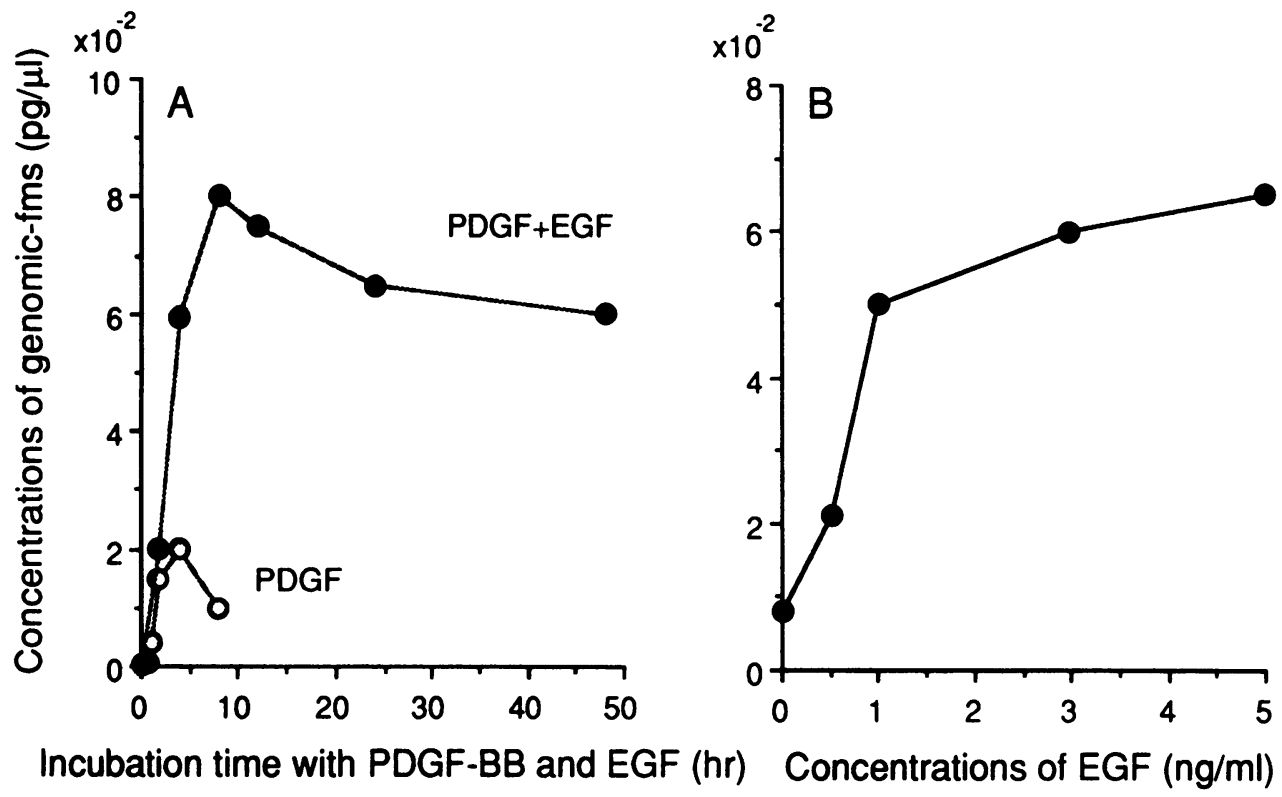

Figure 2. Time- and dose-related expression of $c$-fms mRNA in response to a combination of PDGF$\mathrm{BB}$ and EGF in human aortic smooth muscle cells. The subconfluent cells were cultured with 10 $\mathrm{ng} / \mathrm{ml}$ PDGF-BB and $3 \mathrm{ng} / \mathrm{ml}$ EGF in DMEM and with $10 \mathrm{ng} /$ $\mathrm{ml}$ PDGF-BB for the indicated hours $(A)$ and the specified amounts of EGF for $8 \mathrm{~h}(B)$ in DMEM containing $1 \% \mathrm{FCS}$ at $37^{\circ} \mathrm{C}$ after a $24 \mathrm{~h}$ preincubation in serum-free medium. Each value was estimated by a competitive polymerase chain reaction method as described in Methods.

muscle cells. These cells showed high CAT activity in the presence of $10 \mathrm{ng} / \mathrm{ml}$ PDGF-BB (Fig. 3, $B$ and $C$ ). Furthermore, in the presence of both $10 \mathrm{ng} / \mathrm{ml}$ PDGF-BB and $3 \mathrm{ng} / \mathrm{ml}$ EGF, CAT activity was enhanced twofold as compared to PDGF-BB alone. The EGF effect on CAT activity was less than that on $c$-fms expression demonstrated as mRNA levels, because a fulllength of $c$-fms gene may be required to see the full effect of EGF on $c$-fms expression.

DNA synthesis and scavenger receptor activity. To characterize the effects of PDGF-BB and EGF on cellular functions, we studied $\left[{ }^{3} \mathrm{H}\right]$ thymidine incorporation into DNA. As shown in Table IV, $10 \mathrm{ng} / \mathrm{ml}$ PDGF-BB, $3 \mathrm{ng} / \mathrm{ml}$ EGF and both stimulated the $\left[{ }^{3} \mathrm{H}\right]$ thymidine incorporation into DNA by 2.6-, 1.5-, and 4.7-fold, respectively, whereas IFN- $\gamma$ suppressed the effect of PDGF-BB.

Table II. Effects of Various Factors on mRNA Expression of c-fms in the Presence of PDGF-BB in Human Aortic Medial Smooth Muscle Cells

\begin{tabular}{lcr}
\hline & mRNA level & Fold* \\
\hline No addition & 0.8 & 1.0 \\
EGF $(3 \mathrm{ng} / \mathrm{ml})$ & 8.0 & 10.0 \\
Basic-FGF $(3 \mathrm{ng} / \mathrm{ml})$ & 4.0 & 5.0 \\
Insulin $(100 \mathrm{nM})$ & 0.8 & 1.0 \\
Endothelin 1 (100 nM) & 0.8 & 1.0 \\
PMA (100 nM) & 12.0 & 15.0 \\
Dibutyryl cyclic AMP $(1 \mathrm{mM})$ & 0.8 & 1.0 \\
IFN- $\gamma(50 \mathrm{units} / \mathrm{ml})$ & 0.08 & 0.1 \\
M-CSF $(50 \mathrm{ng} / \mathrm{ml})$ & 0.16 & 0.2 \\
\end{tabular}

Subconfluent human aortic medial smooth muscle cells were cultured with $10 \mathrm{ng} / \mathrm{ml}$ PDGF-BB and the indicated factors in DMEM containing $1 \%$ FCS for $8 \mathrm{~h}$ after a $24 \mathrm{~h}$ preincubation in serum-free medium. Thereafter, total RNA was isolated and levels of mRNA expression were estimated by a competitive polymerase chain reaction method and expressed as genomic $c$-fms concentrations $\left(10^{-2} \mathrm{pg} / \mu \mathrm{l}\right)$. * As compared to no addition.
Furthermore, we estimated cell association and degradation of acetylated LDL in human medial smooth muscle cells. As shown in Fig. 4, acetylated LDL was degraded by medial smooth muscle cells in response to $10 \mathrm{ng} / \mathrm{ml} \mathrm{PDGF-BB}$ and 3 $\mathrm{ng} / \mathrm{ml}$ EGF in the presence of $10 \mu \mathrm{g} / \mathrm{ml}$ acetylated LDL (Fig. 4 ), and a combination of PDGF-BB and EGF enhanced cell association and degradation of acetylated LDL as compared to either PDGF-BB or EGF alone. Whereas no cell association and degradation of acetylated LDL was demonstrated in the absence of those growth factors as we previously reported (4).

Table III. Effects of Various Treatments in the Presence of Both $P D G F-B B$ and EGF on mRNA Expression of c-fms in Human Aortic Medial Smooth Muscle Cells

\begin{tabular}{lcc}
\hline & mRNA level & Fold" $^{4}$ \\
\hline & $10^{-2} \mathrm{pg} / \mu l$ & \\
PDGF-BB $(10 \mathrm{ng} / \mathrm{ml})$ and EGF $(3 \mathrm{ng} / \mathrm{ml})$ & & \\
No treatment & 8.0 & 1.0 \\
PMA preincubation* & 4.0 & 0.5 \\
Staurosporine $(50 \mathrm{nM})^{\ddagger}$ & 4.0 & 0.5 \\
Pertussis toxin $(10 \mathrm{ng} / \mathrm{ml})^{\S}$ & 8.0 & 1.0 \\
M-CSF $(50 \mathrm{ng} / \mathrm{ml})^{\|}$ & 6.0 & 0.75 \\
& & \\
\hline
\end{tabular}

Subconfluent human aortic medial smooth muscle cells were cultured with both $10 \mathrm{ng} / \mathrm{ml}$ PDGF-BB and $3 \mathrm{ng} / \mathrm{ml}$ EGF in DMEM containing $1 \% \mathrm{FCS}$ for $8 \mathrm{~h}$ after a $24 \mathrm{~h}$ preincubation in serum-free medium. * Cells were preincubated with $100 \mathrm{nM}$ PMA for $24 \mathrm{~h}$ before the experiment. ${ }^{\ddagger}$ Cells were preincubated with $50 \mathrm{nM}$ staurosporine for $30 \mathrm{~min}$ before the experiment and further incubated with $50 \mathrm{nM}$ staurosporine for $2 \mathrm{~h}$. ${ }^{\S}$ Cells were preincubated with $10 \mathrm{ng} / \mathrm{ml}$ pertussis toxin for 24 $\mathrm{h}$ before the experiment and further incubated with $10 \mathrm{ng} / \mathrm{ml}$ pertussis toxin for $8 \mathrm{~h}$. "Cells were cultured with $50 \mathrm{ng} / \mathrm{ml} \mathrm{M}-\mathrm{CSF}$ in addition to $10 \mathrm{ng} / \mathrm{ml}$ PDGF-BB and $3 \mathrm{ng} / \mathrm{ml}$ EGF $8 \mathrm{~h}$ after a $24 \mathrm{~h}$ preincubation in serum-free medium. Thereafter, total RNA was isolated and levels of mRNA expression were estimated by a competitive polymerase chain reaction method and expressed as genomic $c$-fms concentrations $\left(10^{-2}\right.$ $\mathrm{pg} / \mu \mathrm{l})$. "As compared to no treatment. 


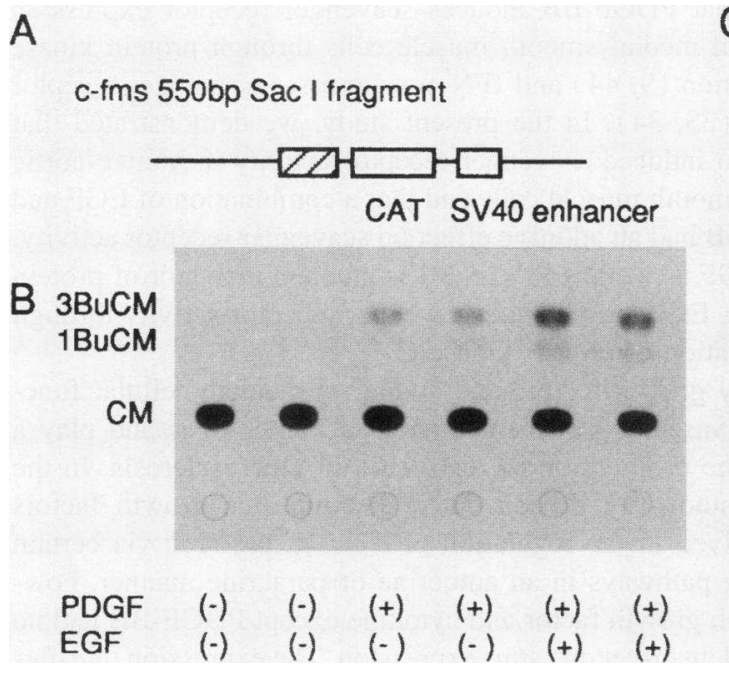

\section{Discussion}

Various cytokines and growth factors secreted by vascular cell components including endothelial cells, monocyte-macrophages, smooth muscle cells, and lymphocytes, are presumed to play important roles in the phenotypic change of vascular smooth muscle cells in an autocrine or paracrine manner (3). Among these factors, the present study demonstrated that a combination of PDGF-BB and either EGF or FGF induced $c$ fms expression in vascular medial smooth muscle cells which do not normally express $c$-fms (4), causing $c$-fms expression to become equivalent to those of human monocyte-derived macrophages and rabbit intimal smooth muscle cells isolated from atherosclerotic lesions, whereas $c$-fms expression by PDGF-BB alone was transient and low, and both EGF and FGF had no

Table IV. Effects of PDGF-BB, EGF, and IFN- $\gamma$ on Cell Growth in Human Aortic Medial Smooth Muscle Cells

\begin{tabular}{lcr}
\hline & $\begin{array}{c}{\left[{ }^{3} \mathrm{H}\right] \text { Thymidine }} \\
\text { uptake }\end{array}$ & $\%$ \\
\hline & dpm/mg cell protein & \\
& $18355 \pm 1380$ & 100 \\
No addition & $48068 \pm 569$ & 262 \\
$10 \mathrm{ng} / \mathrm{ml}$ PDGF-BB & $26686 \pm 1149$ & 145 \\
$3 \mathrm{ng} / \mathrm{ml}$ EGF & $13696 \pm 1761$ & 75 \\
$50 \mathrm{units} / \mathrm{ml} \mathrm{IFN-} \gamma$ & $85308 \pm 7583$ & 465 \\
$10 \mathrm{ng} / \mathrm{ml}$ PDGF-BB $+3 \mathrm{ng} / \mathrm{ml} \mathrm{EGF}$ & $27998 \pm 2139$ & 153 \\
$10 \mathrm{ng} / \mathrm{ml}$ PDGF-BB $+50 \mathrm{units} / \mathrm{ml}$ IFN- $\gamma$ & & \\
\hline
\end{tabular}

Smooth muscle cells were seeded at a density of $10^{5}$ cells $/ \mathrm{ml}$ and medium was replaced with serum-free RPMI 1640 for $48 \mathrm{~h}$ before the experiment. After incubating with human PDGF-BB, human EGF, and/ or human IFN- $\gamma$ in RPMI 1640 containing $1 \%$ fetal calf serum for 24 $\mathrm{h},\left[{ }^{3} \mathrm{H}\right]$ thymidine was added, and incubation was performed for $4 \mathrm{~h}$. The radioactivity in the cells was then determined. Each value represents the mean \pm SD of triplicate wells.
Figure 3. In vitro transcription assay. A 550-bp SacI fragment (-606 to -56 ) containing $5^{\prime}$ noncoding region of $c$-fms genomic DNA was introduced into the pBS-CAT/SV40 plasmid in a sense orientation immediately upstream of the CAT gene. CAT plasmid and control $\beta$-galactosidase plasmid (pSV- $\beta$-Gal) were introduced into subconfluent human aortic smooth muscle cells with lipofectin on a 35-mm dish. Transfected cells were cultured with PDGF-BB (10 $\mathrm{ng} / \mathrm{ml})$ and/ or EGF ( $3 \mathrm{ng} / \mathrm{ml})$ for $4 \mathrm{~h}$ and then cells were harvested for measurement of CAT and $\beta$-galactosidase activity. The measured CAT activity was normalized relative to $\beta$ galactosidase activity. The results for each CAT plasmid tested represent the mean $\pm S D$ for three assays. independent effect on $c$-fms expression. A combination of PDGF-BB and EGF enhanced not only $c$-fms expression but also thymidine incorporation and scavenger receptor activity. It has been suggested that PDGF-BB acts initially to render cells competent to respond to progression factors $(27,28)$. Progression factors such as EGF and FGF not only stimulated the signal induced by PDGF-BB but also functioned to keep $c$ fms expression high, resulting in the acceleration of phenotypic transformation of medial smooth muscle cells to intimal smooth muscle cells.

In addition, PMA, which is an activator of protein kinase $\mathrm{C}$, enhanced the effect of PDGF-BB. This indicates that stimulative effects of either EGF or FGF in combination with PDGF-BB on $c$-fms expression may result from protein kinase $\mathrm{C}$ activation. Previous studies have shown that prolonged exposure of cells to PMA makes cells refractory to PMA, because protein kinase $\mathrm{C}$ activity in PMA-treated cells is down-regulated (29-31). Pretreatment of aortic smooth muscle cells with PMA or staurosporine (protein kinase $C$ inhibitors) suppressed $c$-fms expression in the presence of both PDGF-BB and EGF to only half of that in controls (Table $I$ ). These data suggest that the effect of EGF in combination with PDGF-BB can not only be attributed to protein kinase $C$ activation. We have reported that the $c$-fms expression by PDGF-BB alone is not mediated through protein kinase $\mathrm{C}$ activation because PMA alone did not induce $c$-fms expression and $\mathrm{H} 7$ and staurosporine demonstrated no effects on $c$-fms expression by PDGF-BB (9). Therefore, $c$-fms expression is induced initially by PDGF-BB-specific pathways independent of protein kinase $\mathrm{C}$ and then augmented by EGF and FGF through both protein kinase $\mathrm{C}$-dependent and -independent pathways. Furthermore, additions of either dibutyryl cyclic AMP to PDGF-BB (Table II) or pertussis toxin to a combination of PDGF-BB and EGF (Table III) had no effects on $c$-fms expression, indicating that neither cAMP dependent pathway nor pertussis toxin sensitive $G$ protein were involved in sustained and high expression of $c$-fms in the presence of PDGF-BB.

We demonstrated that IFN- $\gamma$ and M-CSF inhibited the in- 


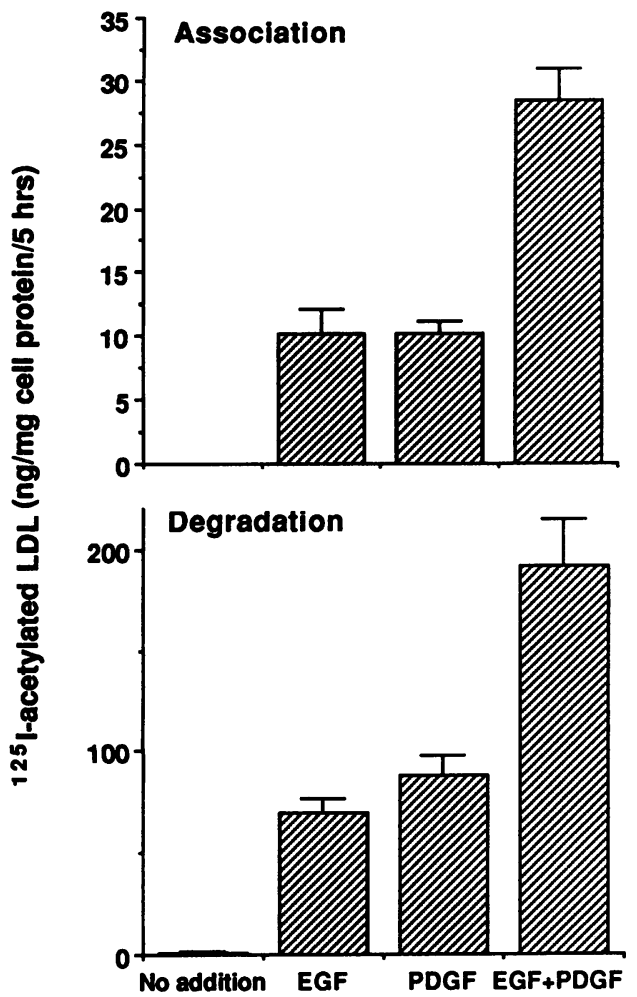

Figure 4. Specific cell association and degradation of ${ }^{125} \mathrm{I}$-acetylated LDL. Subconfluent medial smooth muscle cells were cultured with 10 $\mathrm{ng} / \mathrm{ml}$ PDGF-BB and/or $3 \mathrm{ng} / \mathrm{ml}$ EGF for $8 \mathrm{~h}$ after a $24 \mathrm{~h}$ preincubation in serum-free medium, and further incubated with PDGF-BB and/or EGF in the presence of $10 \mu \mathrm{g} / \mathrm{ml}{ }^{125} \mathrm{I}$-acetylated LDL for $5 \mathrm{~h}$ at $37^{\circ} \mathrm{C}$. Then cell association and degradation of ${ }^{125}$ I-labeled lipoproteins were determined. Nonspecific cell association and degradation were determined by the addition of a 50 -fold excess of unlabeled lipoproteins and were subtracted from total cell association and degradation. Each value represents the mean of triplicate wells.

duction of $c$-fms gene expression by PDGF-BB in human vascular medial smooth muscle cells. IFN- $\gamma$ and M-CSF have been reported to have beneficial effects on reducing the rate of atherogenesis in vitro $(12,32-34)$ as well as in vivo, in which interferon $\gamma$ prevents the progression of atherosclerosis in cholesterol-fed rabbits (35) and M-CSF prevents it in Watanabe heritable hyperlipidemic rabbits $(36,37)$. Therefore, the inhibition of $c$-fms expression in vascular smooth muscle cells by IFN- $\gamma$ and M-CSF appears to be related to the inhibitory process of atherosclerosis, whereas PDGF-BB, EGF, and FGF may be related to the progression of atherosclerosis. M-CSF is known to down-regulate $c$-fms expression at the level of transcription in monocytes (38). Recent reports have characterized the signaling pathway of IFN- $\gamma$ that involves cytoplasmic proteins such as p91 as key factors mediating growth factor signals to the nucleus (39-42). The activities of these proteins, which reside in the cytoplasm as inactive forms, are resistant to protein synthesis inhibition by cycloheximide (43). We observed that a suppressive effect of IFN- $\gamma$ on $c$-fms induction was not affected by cycloheximide. Therefore, our result suggests that these cytoplasmic proteins may be involved in signaling pathways of IFN$\gamma$ for $c$-fms expression.

We recently have demonstrated gene expression of scavenger receptor as well as $c$-fms in vascular smooth muscle cells isolated from atherosclerotic lesions, and proposed that these gene expressions may be related to the phenotypic conversion of vascular smooth muscle cells to foam cells in atheromatous lesions $(4,9,44-47)$. Furthermore, recent studies have demonstrated that PDGF-BB induces scavenger receptor expression in normal medial smooth muscle cells through protein kinase C activation $(9,44)$ and IFN- $\gamma$ suppresses scavenger receptor activity $(33,34)$. In the present study, we demonstrated that EGF also induced scavenger receptor activity in human aortic medial smooth muscle cells and that a combination of EGF and PDGF-BB had an additive effect on scavenger receptor activity. Since EGF as well as PDGF-BB is a potent activator of protein kinase C, EGF may induce scavenger receptor activity through the activation of protein kinase $\mathrm{C}$.

Many growth factors and cytokines regulate cellular functions of vascular wall to maintain its homeostasis and play a role in the progression or regression of atherosclerosis. In the present study, we demonstrated that multiple growth factors are involved in the regulation of $c$-fms expression via certain signaling pathways in an autocrine or paracrine manner, however, each growth factor and cytokine except PDGF-BB had no independent effect on $c$-fms expression. The expression of $c$-fms may explain characteristic aspects of transformation of vascular smooth muscle cells to phagocytic phenotype. Since gene expression of $c$-fms in smooth muscle cells coincides with the phenotypic conversion of medial smooth muscle cells to intimal smooth muscle cells, $c$-fms induction by different growth factors in vascular smooth muscle cells may serve as a good model to study complex interactions of growth factors and cytokines in the arterial wall.

\section{Acknowledgments}

This study was supported by a grant for diabetes research from Otsuka Pharmaceutical Co., Ltd.

\section{References}

1. Steinberg, D., S. Parthasarathy, T. E. Carew, J. C. Khoo, and J. L. Witztum. 1989. Beyond cholesterol. Modifications of low-density lipoprotein that increase its atherogenicity. N. Engl. J. Med. 320:915-924.

2. Thyberg, J., U. Hedin, M. Sjolund, L. Palmberg, and B. A. Bottger. 1990. Regulation of differentiated properties and proliferation of arterial smooth muscle cells. Arteriosclerosis. 10:966-990.

3. Ross, R. 1993. The pathogenesis of atherosclerosis: a perspective for the 1990s. Nature (Lond.). 362:801-809.

4. Inaba, T., N. Yamada, T. Gotoda, H. Shimano, M. Shimada, K. Momomura, T. Kadowaki, K. Motoyoshi, T. Tsukada, N. Morisaki et al. 1992. Expression of M-CSF receptor encoded by c-fms on smooth muscle cells derived from arteriosclerotic lesion. J. Biol. Chem. 267:5693-5699.

5. Stanley, E. R., and P. M. Heard. 1977. Factors regulating macrophage production and growth: purification and some properties of the colony stimulating factor from medium conditioned by mouse L cells. J. Biol. Chem. 252:43054312.

6. Clark, S. C., and R. Kamen. 1987. The human hematopoietic colonystimulating factors. Science (Wash. DC). 236:1229-1237.

7. Wong, G. G., P. A. Temple, A. C. Leary, G. J. Witek, Y. C. Yang, A. B. Ciarletta, M. Chung, P. Murtha, R. Kriz, R. J. Kaufman et al. 1987. Human CSF1: molecular cloning and expression of 4-kb cDNA encoding the human urinary protein. Science (Wash. DC). 235:1504-1508.

8. Sherr, C. J., C. W. Rettenmier, R. Sacca, M. F. Roussel, A. T. Look, and E. R. Stanley. 1985. The c-fms proto-oncogene product is related to the receptor for the mononuclear phagocyte growth factor, CSF-1. Cell. 41:665-676.

9. Inaba, T., T. Gotoda, H. Shimano, M. Shimada, K. Harada, K. Kozaki, Y. Watanabe, E. Hoh, K. Motoyoshi, Y. Yazaki, and N. Yamada. 1992. PDGF induces $c$-fms and scavenger receptor genes in vascular smooth muscle cells. $J$. Biol. Chem. 267:13107-13112.

10. Fisher-Dzoga, K., R. M. Jones, D. Vesselinovitch, and R. W. Wissler. 
1973. Ultrastructural and immunohistochemical studies of primary cultures of aortic medial cells. Exp. Mol. Pathol. 18:162-176.

11. Ishibashi, S., N. Yamada, H. Shimano, N. Mori, H. Mokuno, T. Gotohda, M. Kawakami, T. Murase, and F. Takaku. 1990. Apolipoprotein E and lipoprotein lipase secreted from human monocyte-derived macrophages modulate very low density lipoprotein uptake. J. Biol. Chem. 265:3040-3047.

12. Inaba, T., H. Shimano, T. Gotoda, M. Shimada, M. Kawamura, Y. Yazaki, and N. Yamada. 1993. Macrophage colony-stimulating factor regulates both activites of neutral and acidic cholesteryl ester hydrolases in human monocyte-derived macrophages. J. Clin. Invest 92:750-757.

13. Ishibashi, S., T. Inaba, H. Shimano, K. Harada, I. Inoue, H. Mokuno, N. Mori, T. Gotoda, F. Takaku, and N. Yamada. 1990. Monocyte colony-stimulating factor enhances uptake and degradation of acetylated low density lipoproteins and cholesterol esterification in human monocyte-derived macrophages. J. Biol. Chem. 265:14109-14117.

14. Chomczynski, P., and N. Sacchi. 1987. Single-step method of RNA isolation by acid guanidinum thiocyanate-phenol-chloroform extraction. Anal. Biochem. 162:156-159.

15. Gilliland, G., S. Perrin, K. Blanchard, and H. F. Bunn. 1990. Analysis of cytokine mRNA and DNA: detection and quantitation by competitive polymerase chain reaction. Proc. Natl. Acad. Sci. USA. 87:2725-2729.

16. Gotoda, T., N. Yamada, T. Murase, T. Inaba, S. Ishibashi, H. Shimano, S. Koga, Y. Yazaki, Y. Furuichi, and F. Takaku. 1991. Occurrence of multiple aberrantly-spliced mRNAs upon a donor splice site mutation that causes familial lipoprotein lipase deficiency. J. Biol. Chem. 266:24757-24762.

17. Roberts, W. M., L. H. Shapiro, R. A. Ashmun, and A. T. Look. 1992. Transcription of the human colony-stimulating factor-1 receptor gene is regulated by separate tissue-specific promoters. Blood. 79:586-593.

18. Gotoda, T., N. Yamada, M. Kawamura, K. Kozaki, N. Mori, S. Ishibashi, H. Shimano, F. Takaku, Y. Yazaki, Y. Furuichi, and T. Murase. 1991. Heterogeneous mutations in the human lipoprotein lipase gene in patients with familial lipoprotein lipase deficiency. J. Clin. Invest. 88:1856-1864.

19. Gorman, C. M., L. F. Moffat, and B. H. Howard. 1982. Recombinant genomes which express chloramphenicol acetyltransferase in mammalian cells. Mol. Cell. Biol. 2:1044-1051.

20. Herbomel, P., B. Bourachot, and M. Yaniv. 1984. Two distinct enhancers with different cell specificities coexist in the regulatory region of polyoma. Cell. 39:653-662.

21. Havel, R. J., H. A. Eder, and J. H. Bragdon. 1955. The distribution and chemical composition of ultracentrifugally separated lipoproteins in human serum. J. Clin. Invest. 34:1345-1353.

22. Yamada, N., D. M. Shames, J. B. Stoudmire, and R. J. Havel. 1986. Metabolism of lipoproteins containing apolipoprotein B-100 in blood plasma of rabbits: heterogeneity related to the presence of apolipoprotein E. Proc. Natl. Acad. Sci. USA. 83:3479-3483.

23. Goldstein, J. L., Y. K. Ho, S. K. Basu, and M. S. Brown. 1979. Binding site on macrophages that mediates uptake and degradation of acetylated low density lipoprotein, producing massive cholesterol deposition. Proc. Natl. Acad. Sci. USA. 76:333-337.

24. McFarlane, A. S. 1958. Efficient trace-labelling of proteins with iodine. Nature (Lond.). 182:53-54.

25. Bilheimer, D. W., S. Eisenberg, and R. I. Levy. 1972. The metabolism of very low density lipoproteins proteins. I. Preliminary in vitro and in vivo observations. Biochim. Biophys. Acta. 260:212-221.

26. Goldstein, J. L., S. K. Basu, and M. S. Brown. 1983. Receptor-mediated endocytosis of low-density lipoprotein in cultured cells. Methods Enzymol. 98:241-260.

27. Pledger, W. J., C. D. Stiles, H. N. Antoniades, and C. D. Scher. 1977. Induction of DNA synthesis in BALB/c 3T3 cells by serum components: reevaluation of the commitment process. Proc. Natl. Acad. Sci. USA. 74:4481-4485.

28. Wharton, W., E. Leof, W. J. Pledger, and E. J. O'Keefe. 1982. Modulation of the epidermal growth factor receptor by platelet-derived growth factor and choleragen: effects on mitogenesis. Proc. Natl. Acad. Sci. USA. 79:5567-5571.

29. Lee, L., and I. B. Weinstein. 1979. Mechanism of tumor promoter inhibition of cellular binding of epidermal growth factor. Proc. Natl. Acad. Sci. USA. 76:5168-5172.

30. Collins, M. K., and E. Rozengurt. 1982. Binding of phorbol esters to highaffinity sites on murine fibroblastic cells elicits a mitogenic response. J. Cell. Physiol. 112:42-50.

31. Rozengurt, E., M. Rodriguez-Pena, and K. A. Smith. 1983. Phorbol esters, phospholipase $\mathrm{C}$, and growth factors rapidly stimulate the phosphorylation of a Mr 80,000 protein in intact quiescent 3T3 cells. Proc. Natl. Acad. Sci. USA. 80:7244-7248.

32. Fong, L. G., T. A. T. Fong, and A. D. Cooper. 1990. Inhibition of mouse macrophage degradation of acetyl-low-density lipoprotein by interferon- $\gamma$. J. Biol. Chem. 265:11751-11760.

33. Oppenheimer, M. J., J. F. Oram, and E. L. Bierman. 1988. Upregulation of high density lipoprotein receptor activity by $\gamma$-interferon associated with inhibition of cell proliferation. J. Biol. Chem. 263:19318-19323.

34. Geng, Y. J., and G. K. Hansson. 1992. Interferon- $\gamma$ inhibits scavenger receptor expression and foam cell formation in human monocyte-derived macrophages. J. Clin. Invest. 89:1322-1330.

35. Wilson, A. C., R. G. Schaub, R. C. Goldstein, and P. T. Kuo. 1990. Suppression of aortic atherosclerosis in cholesterol-fed rabbits by purified rabbit interferon. Arteriosclerosis. 10:208-214.

36. Inoue, I., T. Inaba, K. Motoyoshi, K. Harada, H. Shimano, M. Kawamura, T. Gotoda, T. Oka, M. Shiomi, Y. Watanabe et al. 1992. Macrophage colony stimulating factor prevents the progression of atherosclerosis in Watanabe heritable hyperlipidemic rabbits. Atherosclerosis. 93:245-254.

37. Shaub, R. G., M. P. Bree, L. L. Hayes, M. A. Rudd, L. Rabbani, J. Loscalzo, and S. K. Clinton. 1994. Recombinant human macrophage colonystimulating factor reduces plasma cholesterol and carraggenan granuloma foam cell formation in Watanabe heritable hyperlipidemic rabbits. Arterioscler. Thromb. 14:70-76

38. Sariban, E., K. Imamura, M. Sherman, V. Rothwell, P. Pantazis, and D. Kufe. 1989. Downregulation of $c$-fms gene expression in human monocytes treated with phorbor esters and colony-stinulating factor 1. Blood. 74:123-129.

39. Larner, A. C., M. David, G. M. Feldman, K. Igarashi, R. H. Hackett, D. S. A. Webb, S. M. Sweitzer, E. F. Petricoin III, and D. S. Finbloom. 1993. Tyrosine phosphorylation of DNA binding proteins by multiple cytokines. Science (Wash. DC). 261:1730-1733.

40. Ruff-Jamison, S., K. Chen, and S. Cohen. 1993. Induction by EGF and Interferon- $\gamma$ of tyrosine phosphorylated DNA binding proteins in mouse liver nuclei. Science (Wash. DC). 261:1733-1736.

41. Sadowski, H. B., K. Shuai, J. E. Darnell Jr., and M. Z. Gilman. 1993. A common nuclear signal transduction pathway activated by growth factor and cytokine receptors. Science (Wash. DC). 261:1739-1744.

42. Shuai, K., G. R. Stark, I. M. Kerr, and J. E. Darnell Jr. 1993. A single phosphotyrosine residue of Stat91 required for gene activation by Interferon- $\gamma$. Science (Wash. DC). 261:1744-1746.

43. Silvennoinen, O., C. Schindler, J. Schlessinger, and D. E. Levy. 1993. Ras-independent growth factor signaling by transcription factor tyrosine phosphorylation. Science (Wash. DC). 261:1736-1739.

44. Pitas, R. E. 1990. Expression of the acetyl low density lipoprotein receptor by rabbit fibroblasts and smooth muscle cells. Up-regulation by phorbol esters. J. Biol. Chem. 265:12722-12727.

45. Dejager, S., M. Mietus-Synder, and R. E. Pitas. 1993. Oxidized low density lipoproteins bind to the scavenger receptor expressed by rabbit smooth muscle cells and macrophages. Arterioscler. Thromb. 13:371-378.

46. Bickel, P. E., and M. W. Freeman. 1992. Rabbit aortic smooth muscle cells express inducible macrophage scavenger receptor messenger RNA that is absent from endothelial cells. J. Clin. Invest. 90:1450-1457.

47. Pitas, R. E., A. Friera, J. Mcguire, and S. Dejager. 1992. Further characterization of the acetyl LDL (scavenger) receptor expressed by rabbit smooth muscle cells and fibroblasts. Arterioscler. Thromb. 12:1235-1244. 